Jurnal Inspirasi Pendidikan
Vol. 10 No. 2 Tahun $2020 \mid$ Hal. $114-124$

\title{
Evaluasi Kinerja Guru Non PNS di SMK Negeri 1 Pabelan
}

\author{
Wahyu Sabatini ${ }^{\text {a, } 1^{*}}$, Wasitohadi ${ }^{\text {b, } 2}$, Yari Dwikurnaningsih ${ }^{\text {c, } 3}$ \\ a,b,c Universitas Kristen Satya Wacana, Indonesia \\ ${ }^{1}$ wahyusabatini15@gmail.com*; ${ }^{2}$ wasitohadi@uksw.edu; ${ }^{3}$ yari.dwikurnaningsih@uksw.edu \\ *korespondensi penulis
}

\section{Informasi artikel}

Received:

April 19, 2020.

Revised :

Juli 10,2020.

Publish :

September 01, 2020

Kata kunci:

Evaluasi

Kinerja Guru

Model PKG

SMK Negeri 1

Pabelan

\begin{abstract}
ABSTRAK
Penelitian ini bertujuan untuk mengevaluasi kinerja guru non-PNS di SMK Negeri 1 Pabelan. Penelitian ini bersifat evaluatif yang menggunakan prosedur Penilaian Kinerja Guru (PKG) yang menilai empat kompetensi guru sesuai standar Undang-undang. Tujuh guru non-PNS di SMK Negeri 1 Pabelan menjadi sample penelitian. Teknik pengumpulan data menggunakan observasi, wawancara, studi dokumen dan angket. Data penelitian dianalisis secara deskriptif kualitatif dan kuantitatif. Hasil penelitian menunjukkan bahwa rata-rata dari komponen pedagogik, kepribadian, sosial dan professional diatas $70(79,88$; 84,$48 ; 73,21$ dan 72,44 berturut-turut), dengan rata-rata kumulatif sebesar 78,19 dan termasuk dalam kategori yang baik. Berdasarkan hasil tersebut dapat disimpulkan bahwa kualitas guru non PNS di SMK N 1 Pabelan telah memenuhi standar kompetensi guru sesuai dengan PERMENPAN RI No. 16 tahun 2007. Dengan demikian diharapkan kinerja guru non PNS yang telah baik ini mampu meningkatkan kualitas pembelajaran di SMK Negeri 1 Pabelan.
\end{abstract}

Keywords:

Evaluation

Teacher Performance

PKG Model

SMK Negeri 1

Pabelan

\begin{abstract}
Non Civil Servant Teacher's Performance Evaluastion at SMK Negeri 1

Pabelan. This study aims to evaluate the performance of non-PNS teachers at SMK Negeri 1 Pabelan. This research is evaluative using the Teacher Performance Appraisal (PKG) procedure that assesses four teacher competencies according to statutory standards. Seven non-PNS teachers at SMK Negeri 1 Pabelan were the research samples. Data collection techniques using observation, interviews, document study and questionnaires. The research data were analyzed descriptively qualitatively and quantitatively. The results showed that the mean of the pedagogic, personality, social and professional components was above 70 (79.88; 84.48; 73.21 and 72.44 respectively), with a cumulative average of 78.19 and included in good category. Based on these results it can be concluded that the quality of non-PNS teachers at SMK N 1 Pabelan has met the teacher competency standards in accordance with the PERMENPAN RI No. 16 of 2007. Thus, it is hoped that the good performance of non-PNS teachers can improve the quality of learning at SMK Negeri 1 Pabelan.
\end{abstract}

Copyright $\overline{(\odot 2020 \text { (Wahyu Sabatini, Wasito Hadi, Yari Dwikurnaningsih). All Right Reserved }}$

How to Cite: Sabatini, W., Wasitohadi, W., \& Dwikurnaningsih, Y. (2020). Evaluasi Kinerja Guru Non PNS di SMK Negeri 1 Pabelan. Jurnal Inspirasi Pendidikan, 10(2), 114-124.

This work is licensed under a Creative Commons Attribution-ShareAlike 4.0 International License. Allows readers to read, download, copy, distribute, print, search, or link to the full texts of its articles and allow readers to use them for any other lawful purpose. The journal hold the copyright.

\section{Pendahuluan}

Kedudukan guru sebagai pendidik menjadi hal yang terus diperhatikan oleh masyarakat terutama dalam hal status kepegawaian yang mana guru berstatus sebagai PNS atau non PNS. Walaupun berbeda, guru mengemban tugas yang sama baik dari segi peran 
dan fungsinya dalam proses pendidikan (Kartono S. , 2009). Bagaimana guru melaksanakan tugasnya akan menjadi penilaian terhadap kinerjanya. Kinerja guru erat kaitannya dengan pembelajaran yang didalamnya memuat interaksi yang mendidik antara guru dan peserta didik (Priansa: 2014). Selain itu, kinerja juga dinilai berdasarkan perencanaan, pelaksanaan, evaluasi dan pemantauan hasil belajar peserta didik dalam kurun waktu tertentu (Mulyasa, 2015). Hal-hal tersebut adalah beberapa hal yang menjadi indikator maupun ukuran tetang kompetensi guru sebagai pendidik dalam pemenuhan tugasnya.

Kemampuan dan keterampilan guru dalam melaksanakan proses pendidikan berpengaruh terhadap kualitas pendidikan. Maka dari itu, terdapat pedoman kompetensi sebagai kemampuan yang harus dimiliki guru yang menjadi dasar kepribadian guru dalam melaksanakan bimbingan pembelajaran dan tugas tambahan secara seimbang serta profesional (Mulyasa, 2017). Guru yang tidak memenuhi standar kompetensi akan berdampak pada buruknya kualitas pendidikan dan kualitas diri peserta didik yang tidak berkembang secara optimal baik dari intelektual dan kepribadian. Oleh sebab itu, perlunya evaluasi yang merupakan pengukuran suatu pekerjaan menggunakan standar penilaian tertentu dan hasilnya digunakan oleh atasan untuk suatu pertimbangan sebelum mengambil keputusan (Wirawan: 2015). Selain itu, disebutkan bahwa penilaian kinerja guru dapat dilihat dari hasil pekerjaan guru yang mencerminkan bagaimana perilaku, kecakapan serta keahliannya (Mulyasa: 2011).

Berdasarkan uraian diatas dapat diketahui bahwa evaluasi penting dan merupakan salah satu fungsi manajemen yang harus dilakukan. Penelitian terdahulu tentang evaluasi kinerja yang dilakukan pada dua puluh tiga guru sekolah menengah atas yang memiliki sertifikat pendidik (Cahyotlogo \& Jumadi, 2017). Penelitian ini dilaksanakan dengan metode deskriptif evaluatif. Hasil penelitian tersebut berguna bagi sekolah-sekolah yang diteliti untuk meningkatkan dan memperbaiki kekurangan guru pada setiap kompetensi yang dinilai.

Sekolah negeri identik dengan tenaga pengajar berstatus PNS namun ditemui SMK Negeri dengan tenaga pengajar lebih banyak guru non PNS. Kompetensi guru non PNS belum diketahui secara menyeluruh disebabkan belum dilakukannya evaluasi kinerja guru. Hal inilah yang menjadi dasar peneliti untuk melaksanakan penelitian ebvaluasi kinerja memggunakan model Penilaian Kinerja Guru (PKG). Penelitian ini dilaksanakan pada guru non PNS di SMK Negeri 1 Pabelan yang bertujuan untuk: 1)Mengevaluasi kompetensi guru non PNS; 2) Mengevaluasi kompetensi kepribadian guru non PNS; 3) Mengevaluasi kompetensi sosial guru non PNS; 4) Mengevaluasi kompetensi profesional; 5) Memberikan rekomendasi hasil penelitian.

\section{Metode}

Penelitian evaluasi kinerja dilaksanakan pada guru non PNS di SMK Negeri 1 Pabelan. Penelitian ini termasuk dalam penelitian evaluatif dengan menerapkan pendekatan mixed method. Pedoman evaluasi yang digunakan adalah PKG tahun 2019 yang dirancang oleh Ditjen GTK. Pedoman PKG mengangkat empat kompetensi yang menjadi standar penilaian terhadap guru mata pelajaran.

Pengumpulan data dilakukan dengan cara mengobservasi, wawancara, angket dan studi dokumen terhadap tujuh guru non PNS dengan penetapan kriteria yaitu sebagai guru mata pelajaran status non PNS; minimal mengajar 24JP dalam seminggu; sebagai wali kelas dan mewakili tiap tahun perekrutan guru. Penilaian dilakukan oleh berbagai pihak yang telah diatur dalam PKG secara proporsional yaitu guru senior atau kepala sekolah 70\%, teman sejawat $10 \%$, peserta didik $10 \%$ dan orang tua $10 \%$. Teknik analisa data dengan cara 
menggabungkan data yaitu antara deskriptif kualitatif dan deskriptif kuantitatif sehingga datadata tersebut saling melengkapi.

Hasil dan Pembahasan

Kompetensi Pedagogik Guru non PNS

Kompetensi pedagogik mencakup tentang bagaimana guru dapat mengelola pembelajaran yang didasari pada pengenalan peserta didik. Terdapat tujuh indikator yang dapat menggambarkan keadaan dan bagaimana kompetensi guru. Beberapa guru non PNS mampu memenuhi indikator yang ada namun perlu ada peningkatan pada komponen tertentu. Pada dasarnya guru mampu mengenal peserta didiknya dan mampu memenuhi tugas guru yang dalam membuat perangkat pembelajaran maupun melaksanakan tugas mengajar. Adapun secara lebih rinci dibahas mengenai kelebihan dan kekurangan dalam Tabel 1 tentang kompetensi pedagogik guru non PNS.

Tabel 1. Koding Kompetensi pedagogik guru non PNS

\begin{tabular}{|c|c|c|c|}
\hline & Kompetensi & Kelebihan & Kekurangan \\
\hline & $\begin{array}{c}\text { Pemahaman } \\
\text { karakteristik pesera didik }\end{array}$ & $\begin{array}{l}\text { - Guru mampu mengenal } \\
\text { nama, sikap yang } \\
\text { kebiasaan siswa di } \\
\text { kelas, serta rata-rata } \\
\text { nilainya. }\end{array}$ & $\begin{array}{l}\text { - Guru kurang } \\
\text { memahami karakter } \\
\text { peserta didik secara } \\
\text { spiritual, emosional } \\
\text { dan moral }\end{array}$ \\
\hline & $\begin{array}{l}\text { Penguasaan } \\
\text { belajar dan } \\
\text { pembelajaran }\end{array}$ & $\begin{array}{lr}\text { - Guru merencanakan } \\
\text { aktivitas r belajar } \\
\text { dengan bervariasi dan } \\
\text { mampu melibatkan } \\
\text { aktivitas berpikir kritis }\end{array}$ & $\begin{array}{l}\text { - Guru kurang } \\
\text { memberikan motivasi } \\
\text { kepada peserta didik } \\
\text { yang kurang berhasil } \\
\text { dalam pembelajaran }\end{array}$ \\
\hline & $\begin{array}{l}\text { Pengembangan } \\
\text { kurikulum }\end{array}$ & $\begin{array}{lr}\text { - } & \text { Guru mampu membuat } \\
\text { silabus dan RPP sesuai } & \text { dengan kurikulum, } \\
\text { karakteristik peserta } & \text { dan } \\
\text { didik } & \text { menyesuaikan materi } \\
\text { dengan ranteks } & \text { kohidupan sehari-hari } \\
\end{array}$ & $\begin{array}{lr}\text { - Guru } & \text { kurang } \\
\text { menambahkan } & \\
\text { informasi } & \text { yang } \\
\text { mutakhir } & \text { untuk } \\
\text { melengkapi } & \text { materi } \\
\text { pembelajaran } & \\
\end{array}$ \\
\hline & $\begin{array}{l}\text { Pembelajaran } \\
\text { mendidik }\end{array}$ & $\begin{array}{lr}\text { Guru terbuka terhadap } \\
\text { pertanyaan peserta } \\
\text { didik; } & \text { dapat } \\
\text { melaksanakan proses } \\
\text { pembelajaran secara } \\
\text { sistematis disertai } \\
\text { dengan penerapan } \\
\text { berbagai metode dan } \\
\text { media pembelajaran } \\
\text { yang beragam. }\end{array}$ & $\begin{array}{l}\text { - Guru masih banyak } \\
\text { mendominiasi } \\
\text { pembelajaran dan } \\
\text { kurang } \\
\text { memperhatikan } \\
\text { alokasi waktu } \\
\text { pembelajaran. }\end{array}$ \\
\hline & $\begin{array}{l}\text { Pengembangan potensi } \\
\text { peserta didik }\end{array}$ & $\begin{array}{l}\text { - Guru melaksanakan } \\
\text { bimbingan disaat dan } \\
\text { diluar pembelajaran; }\end{array}$ & $\begin{array}{ll}\text { - } & \text { Guru kurang } \\
\text { menumbuhkembangk } \\
\text { an kreativitas peserta }\end{array}$ \\
\hline
\end{tabular}




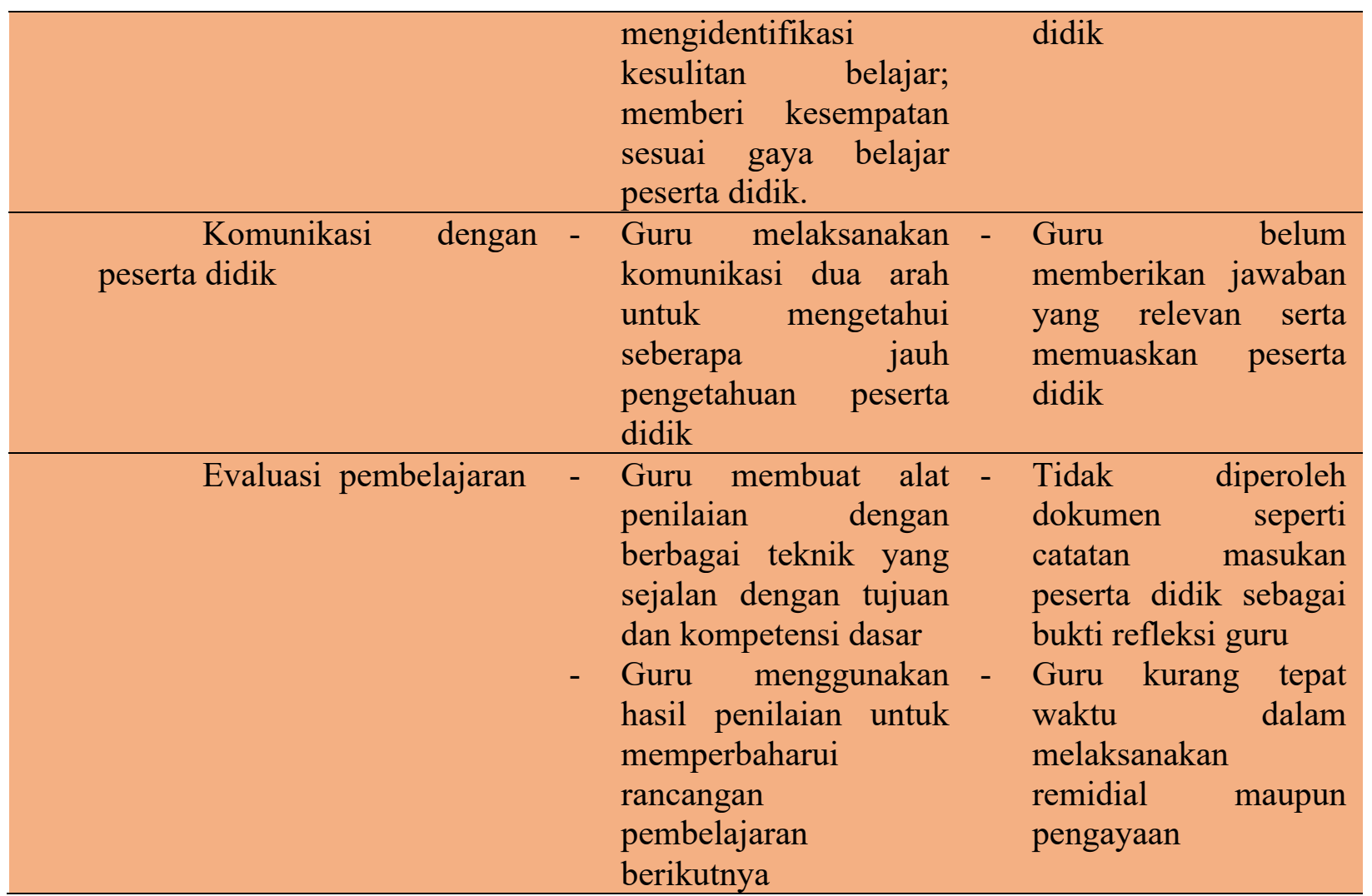

Hasil penilaian ini berdasarkan penilaian guru senior yang ditunjuk oleh kepala sekolah. Hasil yang diperoleh adalah sebagai berikut:

Tabel 2. Hasil PKG kompetensi pedagogik

\begin{tabular}{cccc}
\hline No & Nama & Nilai & Kategori \\
\hline I & SW & 91,6 & Amat Baik \\
\hline 2 & TS & 75 & Cukup \\
\hline 3 & UK & 78,5 & Baik \\
\hline 4 & TA & 78,5 & Baik \\
\hline 5 & IL & 75 & Cukup \\
\hline 6 & MB & 78,5 & Baik \\
\hline 7 & PY & 82, I & Baik \\
\hline & Rata-rata & 79,88 & Baik
\end{tabular}

Hasil diatas memperlihatkan bahwa guru non PNS pada kompetensi pedagogik memiliki kualitas tergolong baik. Hasil penelitian ini sesuai dengan hasil penelitian terdahulu yang dilakukan pada salah satu SMP di Kabupaten Bengkulu Utara mana kompetensi ini dalam kategori yang baik (Nugroho, Rohiat dan Djuwita, 2017). Hasil ini juga sejalan dengan penelitian yang menyatakan bahwa guru yang telah memiliki sertifikat pendidik memiliki kompetensi pedagodik yang baik (Cahyotlogo \& Jumadi, 2017). Evaluasi ini juga sama dengan penelitian yang dilakukan pada guru IPS SMP pada Kab. Kebumen memiliki presentase $88 \%$ termasuk dalam kategori baik (Widarsih \& Faraz, 2016). Hasil penelitian komparatif antara guru PNS dan non PNS berkaitan dengan kompetensi pedagogik pada keduanya tidak memiliki perbedaan yang berarti dimana memiliki hasil yang baik untuk aspek-aspek dari persiapan sampai evaluasi pembelajaran. Dengan melihat penelitian terdahulu terdapat perbedaan subjek penelitian yang mana pada penelitian terdahulu yaitu guru yang bersertifikat pendidik dan guru PNS sedangkan pada penelitian ini memiliki subjek 
guru non PNS dengan perbedaan lama masa kerja dan sebagai pengampu pelajaran yang berbeda. Dengan demikian, dapat diperoleh simpulan pada aspek kompetensi pedagogik guru non PNS memiliki kriteria yang baik.

Melalui hasil penelitian diatas, kompetensi pada guru non PNS bahwa guru mampu melakukan diagnosa perilaku sebagai karakteristik peserta didik. Hal ini memudahkan guru dalam memetakan materi yang sesuai dengan karakteristik peserta didik (Rachmawati \& Daryanto, 2013). Selain daripada itu, dengan perancangan RPP menandakan bahwa guru melakukan persiapan pembelajaran yang baik sehingga pembelajaran dilakukan secara sistematis dan terarah tanpa melakukan improvisasi yang tidak jelas. Komunikasi yang dilakukan terarah pada hal-hal yang bersifat edukatif mampu menciptakan hubungan yang harmonis (Rachmawati \& Daryanto, 2013). Dengan baiknya kompetensi pedagogik pada guru dapat membawa dampak positif terhadap proses pembelajaran.

\section{Kompetensi Kepribadian Guru Non PNS}

Kompetensi kepribadian guru membahas mengenai bagaimana guru mampu memiliki tindakan yang sesuai dengan norma-norma dalam berperilaku sehari-hari. Terdapat tiga indikator pada kompetensi ini. Maka dari itu dilakukan pengamatan dan juga wawancara terhadap warga sekolah sehingga didapatkan data yang pada dasarnya guru mencerminkan kepribadian yang dewasa, mantap dan bertanggungjawab. Data terdapat dalam Tabel 3 tentang kompetensi guru non PNS.

Tabel 3. Koding Kompetensi Kepribadian Guru Non PNS

\begin{tabular}{|c|c|c|c|}
\hline & Kompetensi & Kelebihan & Kekurangan \\
\hline & $\begin{array}{l}\text { Bertindak } \\
\text { norma-norma dan } \\
\text { nasional }\end{array}$ & $\begin{array}{lr}\text { - } & \text { Guru mampu memiliki } \\
\text { perilaku baik, saling } \\
\text { menghormati dan } \\
\text { menghargai rekan } \\
\text { sekerja sehingga } \\
\text { muncul kerja sama } \\
\text { yang baik. }\end{array}$ & $\begin{array}{lr}\text { - } & \text { kurang } \\
\text { menyinggung nilai } \\
\text { nasionalisme dan } \\
\text { cinta tanah air } \\
\text { kedalam pembelajaran }\end{array}$ \\
\hline & $\begin{array}{l}\text { Pribadi yang dewasa } \\
\text { dan teladan }\end{array}$ & $\begin{array}{l}\text { Guru mampu } \\
\text { berperilaku secara } \\
\text { sopan baik dalam } \\
\text { bertutur kata maupun } \\
\text { berpenampilan dan } \\
\text { terbuka terhadap saran } \\
\text { maupun masukan dari } \\
\text { teman sekerjanya }\end{array}$ & $\begin{array}{lr}\text { Guru belum } & \text { pernah } \\
\text { meminta } & \text { rekan } \\
\text { sekerja } & \text { untuk } \\
\text { mengobservasi } & \\
\begin{array}{l}\text { pembelajaran } \\
\text { dilakukan }\end{array} & \text { yang }\end{array}$ \\
\hline & $\begin{array}{l}\text { Etos kerja, tanggung } \\
\text { jawab dan kebanggaan menjadi } \\
\text { guru }\end{array}$ & $\begin{array}{l}\text { - Guru memenuhi } \\
\text { tuntutan kerja sesuai } \\
\text { jam mengajar dan } \\
\text { tugas tambahan } \\
\text { - Guru merasa bangga } \\
\text { dalam menjalankan } \\
\text { profesinya }\end{array}$ & $\begin{array}{l}\text { - Guru kurang } \\
\text { menggunakan waktu } \\
\text { luang untuk hal yang } \\
\text { produktif }\end{array}$ \\
\hline
\end{tabular}

Tabel 4. Hasil PKG kompetensi Kepribadian 


\begin{tabular}{cccc}
\hline No & Nama & Nilai & Kategori \\
\hline I & SW & 75 & Cukup \\
\hline 2 & TS & 91,6 & Amat Baik \\
\hline 3 & UK & 83,3 & Baik \\
\hline 4 & TA & 83,3 & Baik \\
\hline 5 & IL & 83,3 & Baik \\
\hline 6 & MB & 91,6 & Amat Baik \\
\hline 7 & PY & 83,3 & Baik \\
\hline & Rata-rata & 84,48 & Baik
\end{tabular}

Hasil PKG memperlihatkan bahwa kepribadian guru non PNS berada pada kriterian yang baik yang mengisyaratkan bahwa guru non PNS memiliki perilaku dan tindakan yang sesuai dengan norma yang berlaku dalam masyarakat. Sama hal nya dengan penelitian terdahulu pada SMP di Kebumen yang menyatakan bahwa kepribadian guru IPS dalam kategori sangat baik dengan jumlah presentase 93,09\% (Widarsih \& Faraz, 2016). Kejadian ini sejalan pula pada hasil penelitian dengan objek guru PKn yang memiliki kualitas kepribadian yang baik (Dwintari, 2017) sesuai dengan Standar Nasional Pendidikan yang dijelaskan pada pasal 28 ayat $3 \mathrm{~b}$. Melalui penelitian terdahulu pada dasarnya memiliki perbedaan pada alat atau model evaluasi dengan indikator yang berbeda. Perbedaan ini terletak pada penggunaan model evaluasi yaitu model benchmaking (Widarsih \& Faraz, 2016) sedangkan pada penelitian ini dengan model PKG. Hasil penelitian terdahulu pada kompetensi kepribadian diperoleh predikat sangat baik sedangkan pada penelitian ini guru non PNS memiliki kompetensi kepribadian yang baik.

Berdasarkan hasil evaluasi kompetensi kepribadian diatas dapat disimpulkan bahwa kepribadian guru non PNS memiliki kriteria yang baik. Tentu hal ini berdampak pada kualitas peserta didiknya, yaitu menjadi isnspirasi baik dalam etika, moral, dan pengetahuan membentuk kepribadian siswa yang berbudi luhur yang tercermin dari bagaimana ia bertindak dan bersikap dalam kesehariannya (Rachmawati \& Daryanto, 2013). Hal ini terjadi karena apa yang dilihat dan dirasakan oleh peserta didik dari perilaku guru berdampak pada kebiasaan belajar siswa (M, 2018). Dengan ini, guru non PNS mampu membawa pengaruh bagi kehidupan peserta didik melalui kehidupan disekolah.

\section{Kompetensi Sosial Guru Non PNS}

Kompetensi sosial adalah kecakapan guru dalam berinteraksi secara efektif baik dengan peserta didik, teman sejawat, orang tua murid maupun dengan stake holder. Pada kompetensi ini terdapat dua indikator yang keduanya berhubungan dengan tugas guru didalam dan diluar kelas. Pemenuhan indikator kompetensi sosial dapat dibuktikan dengan keikutsertaan kegiatan didalam dan diluar sekolahan yang didokumentasikan sehingga terdapat bukti administratif. Kompetensi ini juga berbicara mengenai pemanfaatan media TIK dalam berkomunikasi sehingga menjadi efektif dan efisien. Maka hasil penelitian tedapat dalam Tabel 5 tentang kompetensi sosial guru non PNS.

Tabel 5. Koding Kompetensi Sosial Guru Non PNS

\begin{tabular}{|c|c|c|}
\hline $\begin{array}{l}\text { Sikap inklusif, objektif } \\
\text { dan tidak diskriminatif }\end{array}$ & $\begin{array}{llr}\text { - } & \text { Guru bersifat adil } \\
\text { terhadap semua peserta } \\
\text { didik } \\
\text { - } & \text { Guru mampu menjaga } \\
& \text { hubungan } & \text { yang } \\
\text { harmonis } & \text { terhadap } \\
\text { rekan sekerja } & \end{array}$ & $\begin{array}{l}\text { Guru bersifat pasif } \\
\text { terhadap diskusi- } \\
\text { diskusi yang diadakan } \\
\text { sekolah dalam forum } \\
\text { formal }\end{array}$ \\
\hline \begin{tabular}{c}
\multicolumn{2}{c}{ Komunikasi dengan } \\
sesama guru, peserta didik,
\end{tabular} & $\begin{array}{lr}\text { Guru } & \text { berperan aktif } \\
\text { dalam } & \text { kegiatan- }\end{array}$ & $\begin{array}{l}\text { Guru tidak } \\
\text { mendokumentasikan }\end{array}$ \\
\hline
\end{tabular}




\begin{tabular}{|c|c|c|}
\hline orang tua dan masyarakat & $\begin{array}{l}\text { kegiatan yang } \\
\text { diselenggarakan } \\
\text { sekolah } \\
\text { - Guru dapat berinteraksi } \\
\text { secara lisan maupun } \\
\text { tulisan dengan orang } \\
\text { tua dan masyarakat }\end{array}$ & $\begin{array}{l}\text { keikutsertaan kegiatan } \\
\text { didalam maupun luar } \\
\text { sekolah } \\
\text { Guru kurang } \\
\text { mendayagunakan TIK } \\
\text { sebagai alat bantu } \\
\text { komunikasi kepada } \\
\text { orang tua maupun } \\
\text { masyarakat }\end{array}$ \\
\hline
\end{tabular}

Tabel 6. Hasil PKG kompetensi Sosial

\begin{tabular}{cccc}
\hline No & Nama & Nilai & Kategori \\
\hline I & SW & 75 & Cukup \\
\hline 2 & TS & 91,6 & Amat Baik \\
\hline 3 & UK & 62,5 & Cukup \\
\hline 4 & TA & 75 & Cukup \\
\hline 5 & IL & 62,5 & Cukup \\
\hline 6 & MB & 75 & Cukup \\
\hline 7 & PY & 75 & Cukup \\
\hline & Rata-rata & 73,21 & Cukup
\end{tabular}

Hasil PKG menyatakan bahwa kehidupan sosial guru non PNS termasuk dalam kriteria yang cukup baik sehingga berbeda dengan beberapa penelitian terdahulu yang menyatakan bahwa guru SMA di Kabupaten Kulon Progo memiliki predikat yang baik (Cahyotlogo \& Jumadi, 2017). Berbeda pula dengan hasil penelitian pada guru di Kabupaten Kebumen yang masuk pada presentase diatas $85 \%$ termasuk pada predikat yang baik. Perbedaan yang terjadi dalam penelitian terdahulu ini karena perbedaan indikator dalam model evaluasi. Dalam PKG setiap indikator harus dibuktikan dengan adanya bukti administratif dan bukan hanya data pengamatan dan wawancara sehingga mempengaruhi penilaian dalam setiap itemnya. Dalam hal ini, guru non PNS memiliki kelemahan dalam medokumentasikan dan mengadministrasikan kegiatan yang dilakukan secara individu maupun dengan kolektif. Oleh sebab itu, guru non PNS perlu memperbaiki administrasi dan pergaulan yang berkaitan dengan kompetensi sosial dengan cara mulai mendokumentasikan kegiatan bersama warga sekolah maupun masyarakat sehingga dapat mengingkatkan keterampilan sosial guru (Hakim, 2015).

Hasil yang cukup baik pada kompetensi ini dapat berarti bahwa guru non PNS cukup mampu berinteraksi dengan komponen sekolah dan masyarakat sehingga terjadi hubungan yang bersifat saling menguntungkan (Priansa, 2018). Dengan adanya relasi yang cukup baik antara berbagai pihak maka dapat dikatakan bahwa hubungan antar elemen sekolah dan masyarakat bersifat harmonis. Walaupun demikian, masih terdapat kekurangan guru dalam membuat catatan sebagai dokumen sebagai administrasi guru.

Kompetensi Profesional Guru Non PNS

Kompetensi profesional adalah penguasaan terhadap bidang studi yang diampu dan bagimana melakukan pengembangan diri. Pada kompetensi ini didapatkan data bahwa guru masih perlu meningkatkan kemampuannya sebagai bentuk pengembangan diri baik dengan melakukan penelitian maupun keikutsertaan seminar maupun workshop. Hasil penelitian terdapat dalam tabel 7.

Tabel 7. Koding Kompetensi Profesional Guru Non PNS 


\begin{tabular}{|c|c|c|c|}
\hline & Kompetensi & Kelebihan & Kekurangan \\
\hline & $\begin{array}{l}\text { Penguasaan struktur, } \\
\text { konsep dan pola pikir } \\
\text { keilmuan bidang studi }\end{array}$ & \begin{tabular}{lr} 
- & \multicolumn{2}{l}{ Guru dapat memetakan } \\
SK dan KD pada mata \\
pelajaran \\
diampunya & yang \\
memberikan perhatian \\
khusus pada materi \\
yang diangap sulit oleh \\
peserta didik
\end{tabular} & $\begin{array}{lr}\text { Guru } & \text { kurang } \\
\text { menyertakan } & \\
\text { informasi } & \text { yang } \\
\text { mutakhir } & \text { untuk } \\
\text { melengkapi } & \text { materi } \\
\text { yang } & \text { diberikan } \\
\text { sehingga } & \text { dalam } \\
\text { pembelajaran } & \text { masih } \\
\text { berfokus pada } & \text { materi } \\
\text { yang ada dalam buku } \\
\text { paket }\end{array}$ \\
\hline & $\begin{array}{l}\text { Pengembangan } \\
\text { keprofesian }\end{array}$ & $\begin{array}{l}\text { - Guru memiliki jurnal } \\
\text { pembelajaran untuk } \\
\text { mencatat pelaksanaan } \\
\text { pembelajaran berkaitan } \\
\text { dengan materi yang } \\
\text { disampaikan }\end{array}$ & $\begin{array}{l}\text { - Guru tidak memiliki } \\
\text { catatan evaluasi diri } \\
\text { secara tertulis maupun } \\
\text { catatan masukan dari } \\
\text { pimpinan maupun } \\
\text { rekan sejawat } \\
\text { - Guru belum } \\
\text { melaksanakan } \\
\text { pengembangan diri } \\
\text { secara optimal } \\
\end{array}$ \\
\hline
\end{tabular}

Tabel 8. Hasil PKG kompetensi Profesional

\begin{tabular}{cccc}
\hline No & Nama & Nilai & Kategori \\
\hline I & SW & $82, I$ & Baik \\
\hline 2 & TS & 75 & Cukup \\
\hline 3 & UK & 75 & Cukup \\
\hline 4 & TA & 62,5 & Cukup \\
\hline 5 & IL & 75 & Cukup \\
\hline 6 & MB & 75 & Cukup \\
\hline 7 & PY & 62,5 & Cukup \\
\hline & Rata-rata & 72,44 & Cukup
\end{tabular}

Hasil PKG menyatakan bahwa keprofesionalan guru terhadap bidang tugasnya berada pada predikat yang cukup baik yang mana sesuai dengan keadaan yang terjadi pada profesionalitas guru yang cukup baik pada salah satu SMP di Kota Salatiga (Oktriany, Sulasmono, \& Iriani, 2018). Tidak jauh berbeda dengan hasil penelitian pada guru Gugus Mangga yang kurang baik dalam hal pengembangan profesionalitas mengajar (Kartono \& Slameto, 2016). Hal-hal diatas sesuadi dengan statemen hasil penelitian yang menyatakan bahwa guru perlu melakukan pengembagan pribadi dan profesional serta meningkatkan produktivitas kinerjanya (Elliott, 2015). Dalam penelitian terdahulu keprofesionalan lebih dikaitkan dengan tanggung jawab dalam belajar dan mengajar (Oktriany, Sulasmono, \& Iriani, 2018) sehingga berbeda halnya dengan hasil penelitian ini dimana guru non PNS juga perlu meningkatkan keprofesionalannya dengan mengikuti kegiatan-kegiatan bersifat ilmiah sehingga mampu memberikan pengetahuan yang lebih luas dalam bidang studinya. Guru juga perlu membuat karya-karya inovatif yang dapat menunjang dalam kemudahan penyampaian 
materi pembelajaran sehingga peserta didik juga memiliki daya kreatifitas dimana hal ini jugatermasuk dalam upaya pengembangan potensi peserta didik.

Hasil penelitian menyatakan keprofesioalan guru non PNS kurang dalam penguasaan pengetahuan yang berkenaan dengan subjek matter sehingga didaktik metodik perlu ditingkatkan (Priansa, 2018). Pada komponen pengembangan diri masih tergolong kurang sehingga perwujudan dari aktualisasi diri kurang sejalan dengan potensi serta kemampuan yang dimiliki guru (Suprayitno, 2019). Dapat dilihat hasil perolehan rerata dari empat kometensi guru berdasarkan PKG dalam gambar 1.

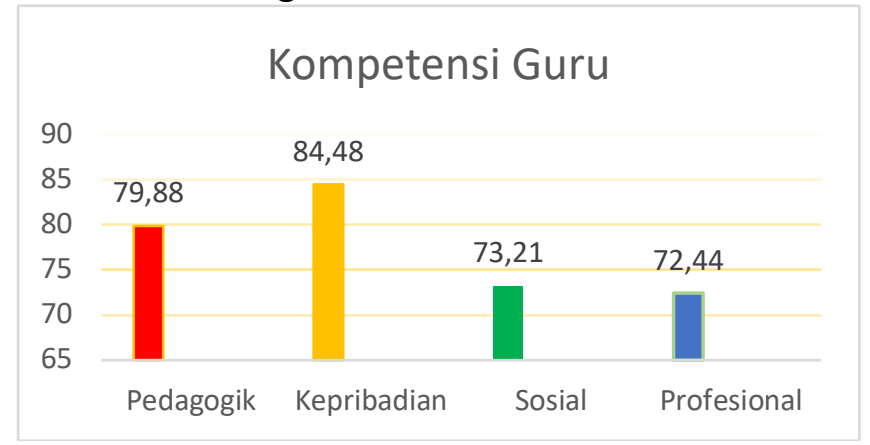

Gambar 1. Rerata empat kompetensi

Hasil rata-rata pada gambar 1 adalah penilaian berdasarkan guru senior. Hasil tersebut kemudian digabungkan dengan penilaian yang diambil dari angket. Diperoleh hasil rata-rata tiap gurunya sebagai berikut :

Tabel 9. Hasil PKG

\begin{tabular}{cccc}
\hline No & Nama & Nilai & Kategori \\
\hline I & SW & 80,98 & Baik \\
\hline 2 & TS & 79,57 & Baik \\
\hline 3 & UK & 77,46 & Baik \\
\hline 4 & TA & $74,4 \mathrm{I}$ & Cukup \\
\hline 5 & IL & 76,61 & Baik \\
\hline 6 & MB & 78,43 & Baik \\
\hline 7 & PY & 79,88 & Baik \\
\hline & Rata-rata & 78,19 & Baik
\end{tabular}

Melalui hasil penggabungan data tersebut diperoleh rata-rata empat kompetensi guru non PNS sebesar 78,19 yang termasuk pada kategori yang baik. Dengan hasil demikian, menyatakan bahwa guru mampu bertanggung jawab melaksankan tupoksinya sebagai pendidik dengan baik yang diwujudnyatakan dalam kegiatan administratif maupun tugas pembelajaran dan tugas tambahan.

\section{Simpulan}

PKG terhadap guru non PNS di SMK Negeri 1 Pabelan dalam kriteria yang baik. Maka dalam hal ini dapat dilihat dari : (1) Kompetensi pedagogik, guru memahami karakteristik peserta didik, dapat membuat perencanaan sampai pada tindak lanjut pembelajaran; (2) Kompetensi kepribadian, guru mencerminkan kepribadian yang dapat menjadi teladan bagi peserta didik dibuktikan degan hidup sesuai tata nilai dan norma yang berlaku di masyarakat; (3) Kompetensi sosial, guru dapat berinteraksi secara efektif dengan anggota sekolah dan elemen masyarakat; (4) Kompetensi profesional, guru dapat menguasi komponen study matter. 
Merujuk pada hasil evaluasi ini, berikut rekomendasi yang dapat diberikan untuk meningkatkan kompetensi guru non PNS di SMKN 1 Pabelan sesuai dengan kekurangankekurangan yang nampak dalam tabel koding tersebut. Maka dari itu, sekolah perlu melakukan pendidikan dan pelatihan sebagai upaya peningkatan dan perbaikan kompetensi guru baik segi knowledge, skill dan attitude guru supaya praktik pendidikan yang dilakukan menjadi berkualitas.

\section{Referensi}

Cahyotlogo, B. D., \& Jumadi. (2017). Pemetaan Kompetensi Pedagogik, Profesional, Kepribadian dan Sosial Guru FisikaSMA di Kabupaten Kulon Progo Pascasertifikasi. Jurnal Fisika dan Keilmuan (JPFK) Vol 3 No 2 September , 96-109. http://doi.org/10.25273/jpfk.v3i2.1199

Dwintari, J. W. (2017). Kompetensi Kepribadian Guru Dalam Pembelajaran Pendidikan Kewarganegaraan Berbasis Penguatan Pendidikan Karakter. Jurnal Pendidikan $\begin{array}{lllllll}\text { Kewarganegaraan } & \text { Vol } & 7 & \text { No } & 2 & \text { Nopember, } & \text { 51-57. }\end{array}$ http://dx.doi.org/10.20527/kewarganegaraan.v7i2.4271

Elliott, K. (2015). Teacher Performance Apprasial: More About Performance or Development. Australian Journal ofTeacher Education Vol 40 No. 9 September, 102116. https://eric.ed.gov/?id=EJ1076425

Hakim, A. (2015). Contribution of Competence Teacher (Pedagogical, Personality,Professional Competence and Social) On the Performance of Learning. The International Journal of Engineering And Science (IJES) Vo;. 4 Issu 2, 1-12. http://www.theijes.com/papers/v4-i2/Version-3/A42301012.pdf

Kartono, A. I., \& Slameto. (2016). Evaluasi Kinerja Guru Bersertifikai. Kelola Jurnal Manajemen Pendidikan Vol 3 No. 2 Juli-Desember, 219-229. https://doi.org/10.24246/j.jk.2016.v3.i2.p219-229

Kartono, S. (2009). Sekolah Bukan Pasar Catatan Otokritik Seorang Guru. Jakarta: PT Kompas Media Nusantara.

M, M. A. (2018). Menjadi Guru Profesional. Jakarta: Prenamedia Group.

Mulyasa, E. (2017). Uji Kompetensi dan Penilaian Kinerja Guru. Bandung: PT Remaja Rosdakarya.

Nugroho, N. T., Rohiat, \& Djuwita, P. (2017). Kinerja Guru Honorer Dalam Pembelajaran Di SMP. Manajer Pendidikan Vol 11 No. 1 Maret, 8-19. https://ejournal.unib.ac.id/index.php/manajerpendidikan/article/view/3191

Oktriany, W. H., Sulasmono, B. S., \& Iriani, A. (2018). Evaluasi Kinerja Guru Bersertifikasi Dengan Model Charlotte Danielson. Kelola Jurnal Manajemen Pendidikan Vol 5 No. 1 Januari-Juni, 24-36. https://doi.org/10.24246/j.jk.2018.v5.i1.p24-36

Priansa, D. J. (2018). Kinerja dan Profesionalisme Guru Fokus Pada Peningkatan Kualitas Pendidikan, Sekolah dan Pembelajaran. Bandung: Alfabeta.

Rachmawati, T., \& Daryanto. (2013). Penilaian Kinerja Profesi Guru dan Angka Kreditnya. Yogyakarta: Gava Media.

Sa'adah, N., Yudana, I. M., \& Sunu, I. G. (2018). Studi Komparatif tentang Perbedaan Kinerja Guru PKN PNS dengan NON PNS (Studi pada SMP Di Kota Singaraja). $e$ Journal Program Sarjana 1 Universitas Pendidikan Ganesha Program Studi Pendiidkan Pancasila dan Kewarganegaraan, 1-10. http://dx.doi.org/10.23887/jpku.v6i3.22068

Suprayitno, A. (2019). Pedoman dan Penyusunan Pengembangan diri Bagi Guru. Yogyakarta: Deepublish. 
Jurnal Inspirasi Pendidikan, VOL.10, NO.2, Edisi Agustus 2020

Evaluasi Kinerja Guru Non PNS Di SMK Negeri 1 Pabelan

Wahyu Sabatini ${ }^{1}$, Wasito Hadi ${ }^{2}$, Yari Dwikurnaningsih ${ }^{3}$

Hal: $114-124$

Widarsih, R., \& Faraz, N. J. (2016). Evaluasi Kinerja Guru IPS SMP Berdasarkan Standar Kompetensi Guru di Kabupaten Kebumen. Harmoni Sosial: Jurnal Pendidikan IPS Vol 3 No 2 September, 177-187. https://doi.org/10.21831/hsjpi.v3i2.7646 